\title{
Cholelithiasis - Epidemiology, Risk Factors and Etiopathogenic Aspects: Up-to-Date
}

\author{
Vladimir Hotineanu, Viorel Moraru*, Petru Bujor and Sergiu Bujor
}

2nd Department of Surgery, Republic Clinic Hospital, University of Medicine and Pharmacy "Nicolae Testemitanu”, Kishinev, Republic of Moldova, Romania

\begin{abstract}
Gallstone disease is the most common gastrointestinal disorder. The best epidemiological screening method to accurately determine the prevalence of gallstone disease is ultrasonography. Gallstone disease is considered a surgical disease since only cholecystectomy is capable of definitively curing the disease. Cholecystectomy is a limited indicator for the prevalence of gallbladder stones, as the perceived threshold for surgery and patient access to care differ markedly. Most patients with gallstones are asymptomatic and the risk of developing symptoms or complications related to gallstones is approximately $1-4 \%$ per year. The common complications of gallstones include biliary colic, acute cholecystitis, common bile duct stones, and gallstone pancreatitis. Although this disease has a low mortality rate, its economic and health impact is significant due to its high morbidity. Many risk factors for gallstone formation are not modifiable such as ethnic background, increasing age, female gender and family history or genetics. Conversely, the modifiable risks for gallstones are obesity, rapid weight loss and a sedentary lifestyle. The recognized risk factors of gallbladder stones for females cannot be extrapolated to men, and this demonstrates the polymorphic character of the etiopathogeny of cholelithiasis and requires further specification. Therefore, there is need for more knowledge of the epidemiological characteristics of gallstone disease in order to better identify therapeutic strategies.
\end{abstract}

\section{Keywords}

Cholelithiasis; Gallstone disease; Epidemiology; Risk factors; Etiopathogenetic aspects; Cholecystectomy

\section{Epidemiologia Litiazei Biliare}

Primele relatări în Europa referitoare la litiaza veziculară (LV) datează din sec. XIV-XV [1,2], iar cele mai numeroase cercetări au fost efectuate în sec. al XX-lea, fapt determinat de o escaladare substanțială a morbidităţii prin această patologie $[3,4]$.

Litiaza veziculară are o etiologie plurifactorială (cu mecanisme intrinsece și extrinsece), caracterizată prin perturbări ale proprietăților de dispersie a particulelor biliare asociate cu procese de aglomerare, agregare și formare a calculilor biliari, punct de plecare a evoluției și persistenței inflamației cronice a peretelui vezical $[2,5,6]$. LV ocupă un loc aparte în patologia zonei hepato-blio-pancreatice, nu numai prin prisma diagnosticului etiologic [7,8], cât și din punct de vedere a răsunetului și impactului complex asupra funcției organelor adiacente $[9,10]$.

La prima vedere aparent simplă, diagnosticarea ecografică a LV nu impune dificultăți deosebite [11-13], pe când precizarea factorilor etiopatogenetici $[14,15]$ cu specificarea funcționalității organelor racordate arborelui biliar (ficat, pancreas, duoden) necesită deja o abordare mult mai complexă și nici pe de parte facilă [16]. În astfel de circumstanțe se impun metode speciale de cercetare, anumite tehnici de ultimă oră fiind actualmente prohibitive pentru majoritatea pacienților sau clinicilor $[17,18]$. Unele controverse privind managementul LV sunt datorate apariţiei la unii bolnavi a unui sindrom dispeptic de tip biliar, „sindromul postcolecistectomie”, ce are o incidență în limite de $10-30 \%[19,20]$.

LV rămâne una dintre cele mai frecvente afecțiuni chirurgicale cu un impact important pentru sistemele de sănătate și practica medicală cotidiană $[21,22]$. În structura afecţiunilor chirurgicale ale organelor cavităţii abdominale, LV deține al 3-lea loc după apendicita și pancreatita acută, cu o tendință clară de creștere a incidenței și prevalenței la nivel mondial $[13,23]$.
Conform OMS anual pe mapamond sunt efectuate circa 2,5 milioane de intervenții asupra căilor biliare (în majoritate colecistectomii laparoscopice) [24-26]. În același timp, litiaza biliară are un impact socioeconomic considerabil, comparabil cu cel al bolilor aparatului cardiovascular. Spre exemplu, în SUA costul total al tratamentului pacienților cu LV a depășit în anul 2005 suma de 5 miliarde USD [15], iar în 2011 deja a depășit 6,2 miliarde USD [7].

Unele cercetări dedicate reevaluării colecistectomiei laparoscopice [27] au constatat că $75-80 \%$ din purtătorii de calculi nu dezvoltă simptome sau complicații $[22,28]$. Cei mai mulți calculi biliari sunt din punct de vedere clinic "silențioși", descoperiți de multe ori incidental în timpul ecografiei abdominale efectuate din alte motive [29]. Astfel, în conformitate cu datele MICOL (Multicenter Italian Study of Cholelithiasis), din cei peste 33.000 de pacienți cu litiază biliară și vârsta cuprinsă între 30-69 ani, s-a consemnat evoluție clinică asimptomatică în $80 \%$ din cazuri. Aceeași tendință se constată și în țările Europei de Est [30]. În grupa de vârstă 31-40 ani doar la 18\% dintre pacienți ar putea fi suspectată prezența calculilor biliari în baza manifestărilor clinice, în grupa de vârstă 41-55 ani și grupa > 55 ani suspiciunea a fost confirmată respectiv în $25 \%$ și doar $12 \%$ observații. Totodată, persoanele cu LV asimptomatică dezvoltă proces inflamator acut cu o rată medie de $2-4 \%$ pe an, fiecare al 10 -lea bolnav pe parcurs a

${ }^{*}$ Corresponding author: Viorel Moraru, MD, PhD, Assoc. Prof. of Surgery, 2nd Department of Surgery, Republic Clinic Hospital, University of Medicine and Pharmacy "Nicolae Testemițanu”, Kishinev, Str. Bogdan Voievod, No 7, ap. 189, 2068, Kishinev, Republic of Moldova, Romania; Tel: +37 (0) 3690537 81; Fax:+37 (0) 3228063 34; E-mail: viorel_moraru@ymail.com

Received March 02, 2014; Accepted March 21, 2014; Published September 20 , 2014

Citation: Hotineanu V, Moraru V, Bujor P, Bujor S. Cholelithiasis-Epidemiology, Risk Factors and Etiopathogenic Aspects: Up-to-Date. Journal of Surgery [Jurnalul de chirurgie] 2014; 10(2): 117-121 [article in Romanian] DOI: 10.7438/1584-9341-10-2-2.

Copyright: (c) 2014 Hotineanu V, et al. This is an open-access article distributed under the terms of the Creative Commons Attribution License, which permits unrestricted use, distribution, and reproduction in any medium, provided the original author and source are credited. 
5 ani de la depistare necesitând tratament chirurgical de urgență pentru colecistită acută litiazică $[26,29,31]$. Totuși tactica expectativă, preferată de gastroenterologi $[1,27,32]$ nu este argumentată, rata complicaţiilor și a mortalității, la fel ca și posibilitatea abordului laparoscopic fiind net diferite în urgență $[23,28]$, comparativ cu tratamentul electiv [33,34].

Indicii epidemiologici de bază sunt reprezentați și de numărul colecistectomiilor efectuate la 100.000 locuitori, cât și mortalitatea postoperatorie. Studiile efectuate arată că odată cu amplificarea incidenței LV există și o creștere a complicațiilor, cum ar fi pancreatita acută biliară sau icterul mecanic litiazic [29,35]. Totodată, numărul de proceduri chirurgicale pentru litiază biliară a crescut semnificativ și constant în țările dezvoltate după1950 [33].

Ulterior, apariţia colecistectomiei laparoscopice în 1989 a condus la o creștere importantă a ratei pacienților colecistectomizați: din 1990 până în $1993 \mathrm{~s}$-a consemnat o escaladare de $28 \%$ a acestui indice $[1,19]$. Această schimbare a fost determinată de abordul mai puțin invaziv, mai acceptabil sub aspect cosmetic, oferind în acelaşi timp un risc chirurgical mai mic comparativ cu procedeul chirurgical "deschis" $[9,21]$. Colecistectomie laparoscopică este în prezent cea mai frecventă operaţie electivă abdominală $[2,5,6,13,16]$.

Conform datelor OMS (WHOSIS Query Service, www.who. int.) în SUA anual sunt efectuate circa 150 colecistectomii la 100.000 locuitori cu o letalitate postoperatorie în limite de la $0,1 \%$ (în clinicile specializate) până la $0,6 \%$ (media pe țară). Autorii occidentali constată că deși rata mortalității prin LV este relativ scăzută, rămân totuși 1092 decese anuale legate de patologia calculilor biliari. Din fericire, mortalitatea s-a diminuat în $\bmod$ constant cu $>50 \%$ între anii 1979 și 2004, iar acest declin reprezintă cea mai mare scădere dintre toate afecțiunile tractului digestiv [14].

Conform datelor Biroului Național de Statistică a Republicii Moldova (www.statistica.md) incidența bolii este de 8-9000/100.000 persoane/an. În ultimii 4 ani se remarcă o tendință variabilă: 8396 cazuri în 2006, 8486 în 2007, 7786 în 2008, 8771 cazuri în 2009. Prevalența afecțiunilor veziculei biliare la populația adultă are o ușoră tendință de creștere de la 52830 cazuri în 2005, 53539 cazuri în 2006, 60772 cazuri în 2007, 55984 cazuri în 2008, 59679 cazuri în 2009.

În literatura de specialitate autohtonă nu am găsit date referitoare la indicii epidemiologici de bază ai litiazei biliare veziculare (numărul de colecistectomii la 100.000 locuitori și rata mortalităţii postoperatorii) pe parcursul ultimilor 5 ani. Datele statistice pe anii 2004 şi 2005 denotă efectuarea a 1585 , respectiv 2585 colecistectomii programate, $\mathrm{cu}$ mortalitate postoperatorie de $0,37 \%$, respectiv $0,29 \%$. Incidența colecistitei litiazice acute la 100.000 locuitori a constituit 85,7 în 2004 și 46,6 în 2005. În 2004 au fost operați de urgență 3085 bolnavi cu o mortalitate postoperatorie de 1,39\%, iar în 2005 au fost 2016 bolnavi operați cu o mortalitate postoperatorie de 1,49\%. Abdomenul acut chirurgical prin colecistită litiazică acută raportat la 100.000 locuitori a constituit 16,0 în 2004 și 11,4 în 2005 [36]. Anual în țara noastră se efectuează peste 25.000 operații adresate patologiei chirurgicale a tractului digestiv, mortalitatea generală postoperatorie constituind 3-10 \% [37]. Chirurgia programată a celor mai răspândite boli digestive chirurgicale (boala ulceroasă a stomacului și duodenului, litiaza biliară, patologia pancreasului, ficatului și colo-rectală, patologia organelor endocrine) constituie până la 30-35\% din numărul total de operații efectuate anual în republică (cca 72.000).

Statisticile estimează că 17-19\% dintre bolnavii operați dezvoltă postoperator precoce sau tardiv diverse o serie de tulburări. Astfel, pentru Republica Moldova litiaza veziculară, constituie o problemă medico-socială importantă [36].
Bineînțeles rezultatele diferite par a fi dependente de circumstanțele locale, de experiența și expertiza echipei medicale, de factori socioeconomici; unii autori occidentali consideră potențial evitabile decesele postoperatorii a bolnavilor colecistectomizați [24]. În acest context cunoașterea factorilor de risc ai litogenezei biliare, indicația chirurgicală corectă pusă în timp util, înante de apariția complicațiilor, explorarea amununțită intraoperatorie vor evita suferințele posoperatorii și litiaza reziduală. [15,18,21,26,28].

\section{Factorii de risc și Etiopatogenie}

Conform concepțiilor contemporane asupra etiopatogeniei litiazei veziculare factorii de risc importanți sunt convențional divizați în două grupe: 1) modificabili și 2) non-modificabili. Diverse cercetări au demonstrat că formarea calculilor biliari este multifactorială $[3,7,35,38]$. Unele caracteristici, cum ar fi etnia, genetica, înaintarea în vârsta și sexul feminin nu pot fi modificate, în timp ce altele (de exemplu, dieta, activitatea fizică, pierderea rapidă în greutate și obezitatea) sunt modificabile (Tabel I) [1,17].

\section{Istoricul Familial și Predilecția Genetică}

Susceptibilitatea genetică este un factor-cheie în evoluţia litiazei biliare, studiile familiale relevând o frecvență de aproape 5 ori mai mare și un risc ridicat la rudele pacienților cu LV [31,39]. Aceste raporturi sunt îndeosebi mai mari la gemenii monozigoți, constituind circa $12 \%$ cazuri, iar în cazul celor dizigoţi aproximativ $6 \%$ din gemeni dezvoltă în aceeași perioadă de timp litiază veziculară biliară [40]. Soții purtătorilor de calculi nu prezintă risc sporit, eliminându-se astfel factorul unui mediu comun (dieta de aceeași natură sau alte obiceiuri alimentare ale membrilor familiei) drept element care determină apariția LV [5].

Într-un studiu realizat de cercetătorii suedezi pe un eșantion de peste 43.000 de perechi de gemeni cu litiază biliară veziculară simptomatică efectele genetice au fost determinate în circa $25 \%$ observaţii, în timp ce influențele de mediu comune cu impactul respectiv au fost specificate în aproximativ 13\% cazuri [40]. Apariţia litiazei biliare reprezintă o interacțiune complexă a ansamblului format de însușirile genetice și factorii mediului, în mod particular a interacţiunii dietă-genă.

Cercetările în domeniul fiziopatologiei litiazei biliare efectuate în decursul ultimilor 10 ani au determinat rolul contribuției a șapte clase generale de gene candidate (în total 55 de gene), care codifică proteinele implicate în formarea calculilor: I) Enzime de reglementare a lipidelor hepatice (colesterol $\alpha$-hidroxilaza), ce pot crește secreţia colesterolului sau să reducă proporţia de acizi biliari / fosfatidilcolină biliară; II) Receptori de lipoproteine cu proteine înrudite, responsabile pentru menținerea normală a metabolismului colesterolului; III)

Tabelul I: Factorii de risc ai litiazei biliare.

\begin{tabular}{|c|c|}
\hline Non-modificabili & Modificabili \\
\hline $\begin{array}{l}\text { Istoricul familial / predispoziția } \\
\text { genetică }\end{array}$ & $\begin{array}{l}\text { Obezitate, sindrom metabolic, diabet zaharat, } \\
\text { dislipidemie }\end{array}$ \\
\hline Apartenență etnică & $\begin{array}{l}\text { Medicamente: ceftriaxon, octreotide, thiazide, } \\
\text { contraceptive }\end{array}$ \\
\hline Sex feminin & Activitate fizică redusă \\
\hline \multirow{6}{*}{$\begin{array}{l}\text { Vârsta } \\
\text { (persoane de vârsta a II-a şi } \\
\text { a III-a) }\end{array}$} & \\
\hline & Scădere rapidă a masei corporale, anorexie \\
\hline & Nutriție parenterală totală \\
\hline & Dietă \\
\hline & $\begin{array}{l}\text { Afecțiuni diverse: ciroza hepatică, boala Crohn, } \\
\text { diverticul duodenal şi coledocian, status } \\
\text { post-rezecție gastrică, vagotomie trunculară, } \\
\text { hiperparatiroidism, infecții ale arborelui biliar, } \\
\text { hemoliză cronică }\end{array}$ \\
\hline & Graviditate \\
\hline
\end{tabular}


Proteine hepatice și intestinale de transport la nivelul membranei celulare (apolipoproteine E și B); IV) Proteine hepatice și intestinale de transport intracelular a colesterinei, sărurilor biliare sau fosfatidilcolinei (cholesterol ester transporting protein - CETP); V) Factorii care reglementează transcripţia lipidelor şi a sărurilor biliare, VI)Colecistokinina și receptori ei (cholecystokinin receptor A-CCKAR), care influenţează motilitatea veziculei biliare; VII) Mucina.

Prezența anumitor tipuri de genotip al apolipoproteinelor din clasa "E" (ce conțin alela apo-E4) este asociată cu un risc crescut de LV colesterinică [41], demonstrată la pacienții care locuiesc în Finlanda, Germania, Spania [25,42,43]. Acest fapt se datorează sintezei semnificativ reduse de acizi biliari, odată cu creșterea absorbției colesterolului din intestin. Ca urmare, la bolnavii cu LV se constată un conținut sporit de fracții hidrofobe de acid desoxicholic. Astfel, în viitor se dorește aplicarea ingineriei genetice în crearea bacteriilor coliforme cu capacitate redusă de sinteză a desoxicolatelor sau terapia adjuvantă în cazul $7 \alpha$ - hidroxilazei sau X-farnesoid receptorilor [44]. Așadar, pornind de la cele mai vechi concepții a predilecţiei genetice la colelitiază, bazate pe anamneza istoricului familial, știinţa medicală modernă a ajuns la etapa analizei propriu-zise a genomului uman, fapt ce oferă posibilitatea cunoașterii și înţelegerii mai profunde a mecanismelor etiopatogenetice de constituire a calculilor biliari.

\section{Vârsta}

Un alt factor major de risc al LV este reprezentat de vârsta. Frecvența depistării calculilor biliari crește odată cu înaintarea în vârstă, în special după 40 de ani; riscul necesităţii tratamentului chirurgical crește în această categorie de 4 -10 ori [35,38,41]. Odată cu vârsta crește numărul de cazuri simptomatice și complicate, ce necesită tratament chirurgical. Datele OMS arată că la persoanele mai tinere de 50 de ani LV apare la 7-11\%, în grupa de vârstă de 60-69 de ani la 11-23\%, iar la persoanele peste 80 de ani afecţiunea are o incidență de 33-50\%. Având în vedere că odată cu îmbătrânirea survine nu numai o creștere a secreției de colesterol în bilă, dar și o scădere a cantităţii de acizi biliari secretaţi cu diminuarea concentraţiei lor cantitative în bilă (urmare a activității scăzute a colesterol- $7 \alpha$ - hidroxilazei) pare a fi legitimă conexiunea directă a LV cu vârsta $[140,54]$. Pe de altă parte, odată cu vârsta se schimbă și tipul de calculi, inițial fiind compuși în principal din colesterol (corespunzător unei secreții crescute de colesterol și saturație de bilă), ulterior se modifică structura lor, fiind mai frecvent depistaţi calculi pigmentari sau micști [24].

\section{Sexul și Hormonii Feminini}

La ora actuală sexul feminin reprezintă un factor de risc al LV unanim recunoscut. La nivel mondial, femeile sunt afectate de LV de circa 2-4 ori mai frecvent, în unele etnii fiind atestat un raport femei/ bărbaţi de 7:1 [22]. Cercetările efectuate arată că în timpul trimestrului al treilea de sarcină la $30 \%$ din gravide apare "sludge" biliar (SB), iar la $2 \%$ apar calculi biliari colesterolici [45]. După travaliu, funcția motorie a vezicii biliare se restabilește și SB dispare la 60-70\% din femeile gravide [46].

În familiile cu predispoziţie pentru această patologie este detectată o rată net superioară a femeilor purtătoare de calculi [41]. Sistematizând succint unele aspecte ale etiopatogeniei LV putem evidenţia următoarele momente: ficatul absoarbe chilomicronii și metabolizează colesterolul cu formarea colatelor și excreția ulterioară a colesterinei în comun cu colate și fosfolipide sub formă de vezicule cu participarea proteinelor colat-transportatoare. Eliminarea veziculelor în bilă suplimentar este asigurată de: 1) sintetizarea esterelor de colesterină (acil- CoA: colesterinacetiltransferaza); 2) transformarea colesterinei în colate (acizi biliari) (7a-colesterolhidrolază, sterol 27- hidroxilaza); 3) sinteza și secreția de lipoproteine cu masă moaleculoară joasă. La rândul său micșorarea concentraţiei acizilor biliari în bila secretată poate fi determinată de următoarele mecanisme: 1) diminuarea biosintezei acizilor biliari primari, colic si chenodezoxicolic, prin inhibarea enzimei reglatoare $7 \alpha$-hidroxilaza și reducerea cu circa $25 \%$ din activitate ei [130]; 2) exacerbarea catabolismului acizilor biliari cu micșorarea cantităţii de acizi biliari (de la 5,45 \pm 0,22 spre 3,38 \pm 0,27 $\mathrm{mmol})$ condiţionată de creșterea ciclicităţii circulaţiei entero-hepatice ale acestora.

Estrogenii sporesc conţinutul de colesterol în bilă prin acţiunea asupra receptorilor lipoproteinelor de masă moleculară joasă și stimulează reabsorbţia colesterolului de către hepatocite [47]. Evoluează aşa-zisa colestază clasică "estrogenă fragedă", caracterizată prin creșterea raportului colesterol/fosfolipide pe membrana canaliculară cu diminuarea vitezei și volumului secreţiei bilei hepatice [48]. Datele gamma-scintigrafiei dinamice în colestaza cronică se reflectă prin diminuarea funcțiilor hepatice de absorbție (la cca 62\% bolnavi) și de excreţie (respectiv la 77\% pacienţi) [2]. Prin prisma acestor fenomene ( $\uparrow$ sintetizării colesterolului; $\uparrow$ secreţiei de colesterină; $\downarrow$ raportului acizi biliari / colesterină) devine clar de ce drept factori de risc ai constituirii calculilor biliari colesterinici reprezintă sexul feminin, graviditate și administrarea contraceptivelor [49].

Literatura consemnează studii sporadice referitoare la litiaza biliară la bărbaţi [50-53]. De regulă, sursele accesibile analizează problema în cauză fie pe cohorte generale ale populaţiei (bărbaţi și femei), fie doar prin prisma unor particularități epidemiologice, clinico-evolutive, de tratament ș.a.m.d., la fel realizate pe eșantioane mixte [28,54].

În acest fel, la ora actuală datele asupra litiazei veziculare la bărbaţi rămân incerte și necunoscute, datele prezentate de diverși autori adesea sunt contradictorii sau sunt în conflict direct cu statisticile concepţiilor unanim recunoscute [50,55,56]. Anume această discrepanţă a și constituit un motiv și imbold puternic pentru efectuarea cercetărilor noastre în dorinţa de a elucida anumite aspecte ale problemei.

În linii generale în funcție de sex LV survine la circa 7,9\% bărbaţi și $16.6 \%$ femei din ţările de vest, 3\%, respectiv 15\% în ţările Asiei; în ţările din Africa cu o rată generală sub $5 \%$, în China afectează aproximativ $4,2 \%$ dintre bărbaţi și $11 \%$ de femei $[12,15,19]$. Și totuși, datele literaturii recent publicate indică o creștere a incidenţei LV la bărbaţi [8], iar în grupa de vârstă peste 70 de ani această diferență aproape că dispare $[26,41,57]$, ca urmare a creșterii numărului de cazuri de litiază biliară la persoanele de gen masculin [51-53].

În anul 2009 un grup de autori chinezi a publicat incidenţa LV pe un eșantion de 3573 bolnavi (1825 bărbaţi și 1748 femei, repartizaţi uniform în funcţie de grupele de vârstă), cu rezultate surprinzătoare, incidența afecţiunii fiind practic similară - 9,9\% la bărbaţi și 11,6\% la femei [8]. Conform rezultatelor cercetărilor proiectului Italian de studiu în domeniul litiazei biliare (MICOL), publicate în 1995 prevalenţa LV pe parcursul unui an crește circa cu $0,47 \%$ la bărbaţi, comparativ cu $0,67 \%$ la femei [24]. În continuarea proiectului în 2008 au fost reevaluate datele bolnavilor incluși inițial în cercetare, rata cumulativă a incidenţei LV pe an constituind deja $0,67 \%$ la bărbaţi și $0,81 \%$ la femei cu o diminuare a diferenței în funcţie de sex [54].

Discrepanţă evidentă se constată și la capitolul estimării altor factori de risc ai evoluţiei litiazei biliare la bărbaţi [14,23]. Astfel, dacă la femei rolul obezităţii, nivelului sporit de trigliceride, vârstei și a administrării derivaţilor progesteronului sunt unanim acceptate, în cazul bărbaţilor datele sunt contradictorii [8].

Dacă unele cercetări $[57,58]$ susţin că la bărbaţi dislipidemia nu reprezintă factor etiologic de risc și nu se corelează cu constituirea calculilor biliari, alţi autori contestă aceste păreri [14,31,54]. Pare a fi plauzibilă și argumentată concepţia C. Thijs și colab. [59], conform căreia determinarea arbitrară (la un interval de timp scurt) 
a concentrației lipidelor plasmatice poate fi doar o reflectare slabă a nivelului plasmatic ,în perioada critică" de constituire a calculilor biliari, susţinută și de alţi autori $[46,60]$. În acest caz, relaţia de cauzalitate între nivelul lipidelor și LV poate fi subestimată. În confirmarea acestei ipoteze vom prezenta două exemple: după colecistectomie la pacienţi se consemnează diminuarea concentraţiei lipidelor plasmatice, în timp ce în cazul crizelor de colică biliară survine escaladarea fenomenului de sludge biliar cu mărirea dimensiunilor microcalculilor, concomitent fiind stabilită o creștere a concentraţiei lipidelor plasmatice $[2,35,45]$.

$\mathrm{Cu}$ toate acestea, recent s-a demonstrat, că bărbații obezi secretă în general mai mulți acizi biliari și fosfolipide în bilă decât femeile supraponderale, prin urmare, bila lor este mai puțin litogenică și ei nu au tendinţă de a forma calculi biliari $[8,53]$. Mai mult decât atât, se menţionează o conexiune directă între diminuarea și fluctuaţia masei corporale (weight cycling) la persoanele obeze și riscul sporit de constituire a calculilor biliari [54]. Regimul hipocaloric utilizat la pacienţii obezi dă naștere la așa zisul „nămol biliar” cu litogeneză în circa $25-50 \%$ cazuri [61]. O confirmare o reprezintă următoarea observație: by-pass-ul chirurgical pentru obezitate sporește riscul LV: $40 \%$ dintre pacienţi dezvoltă calculi în termeni de 6 luni postoperatorii [21,62]. Pierderea în greutate este însoțită de niveluri ridicate de mucină și calciu în bila veziculară, factori favorizanți ai „nămolului biliar” și litogenezei $[1,47]$.

Pe lângă acestea, pierderea din masa corporală induce o diminuare considerabilă a sintezei hepatocelulare de glutationă (aproximativ la jumătate) - factor cu semnificaţie deosebită în asigurarea apărării antioxidativ, contribuind în acest sens creșterii metaboliţilor de peroxidare lipidică, și respectiv stress-ului oxidativ al epiteliului veziculei biliare cu alterarea lui, fiind astfel create condiţii mai prielnice litogenezei [52,62].

În același timp, la bărbaţi nu se constată vreo conexiune directă între modul de viaţă (activitatea fizică) și riscul evoluţiei LV $[7,41]$. Aceste concepţii sunt confirmate și de studiul realizat de Chang Y. și colab. (2008) [50], efectuat selectiv pe un lot de 440 bolnavi nonobezi și non-diabetici cu litiază biliară, studiu care nu a stabilit vreo concordanţă între prezenţa calculilor și indicele masei corporale, nivelul de colesterol și trigliceride.

\section{Concluzii}

Factorii de risc ai LV recunoscuți pentru persoanele feminine nu pot fi extrapolaţi “mecanic" și la bărbați, fapt ce demonstrează încă o dată polimorfismul etiopatogeniei LV și necesită cercetări suplimentare.

\section{Conflict de Interese}

Autorii nu declară niciun conflict de interese.

\section{Bibliografie}

1. Conte D, Fraquelli M, Giunta M, Conti CB (2011) Gallstones and liver disease: an overview. J Gastrointestin Liver Dis 20: 9-11.

2. Carey MC (1993) Pathogenesis of gallstones. Am J Surg 165: 410-419.

3. Trowbridge RL, Rutkowski NK, Shojania KG (2003) Does this patient have acute cholecystitis? JAMA 289: 80-86.

4. Lammert F, Matern S (2005) The genetic background of cholesterol gallstone formation: an inventory of human lithogenic genes. Curr Drug Targets Immune Endocr Metabol Disord 5: 163-170.

5. Dowling RH (2000) Review: pathogenesis of gallstones. Aliment Pharmacol Ther 14 Suppl 2: 39-47.

6. Festi D, Reggiani ML, Attili AF, Loria P, Pazzi P, et al. (2010) Natural history of gallstone disease: Expectant management or active treatment? Results from a population-based cohort study. J Gastroenterol Hepatol 25: 719-724.

7. Stinton LM, Shaffer EA (2012) Epidemiology of gallbladder disease: cholelithiasis and cancer. Gut Liver 6: 172-187.
8. Sun $\mathrm{H}$, Tang $\mathrm{H}$, Jiang $\mathrm{S}$, Zeng L, Chen EQ, et al. (2009) Gender and metabolic differences of gallstone diseases. World J Gastroenterol 15: 1886-1891.

9. Bratucu E, Ungureanu D. Litiaza veziculara In Angelescu N. editor, Tratat de patologie chirurgicala. Vol. II. Bucure?ti: Editura Medicala; 2003: 1914-1924.

10. Hirota M, Takada T, Dervenis C (2007) Diagnostic criteria and severity assessment of acute cholecystitis: Tokyo Guidelines. J Hepatobiliary Pancreat Surg: 78-82.

11. Ahmed M Diggory R (2011) The correlation between ultrasonography and histology in the search for gallstones. Ann R Coll Surg Engl 93: 81-83.

12. Kratzer W, Mason RA, Kächele V (1999) Prevalence of gallstones in sonographic surveys worldwide. J Clin Ultrasound 27: 1-7.

13. Pinto A, Reginelli A, Cagini L, Coppolino F, lanora A. Accuracy of ultrasonography in the diagnosis of acute calculous cholecystitis: review of the literature. Crit Ultrasound J. 2013; 5(Suppl 1): S11. doi:10.1186/2036-7902-5-S1-S11.

14. Everhart JE, Ruhl CE (2009) Burden of digestive diseases in the United States part I: overall and upper gastrointestinal diseases. Gastroenterology 136: 376-386.

15. Shaffer EA (2005) Epidemiology and risk factors for gallstone disease: has the paradigm changed in the 21st century? Curr Gastroenterol Rep 7: 132-140.

16. Hotineanu V, Ferdohleb A, Hotineanu A (2005) [Surgical strategy in the management of benign obstructive jaundice]. Chirurgia (Bucur) 100: 241-250.

17. Marschall HU, Einarsson C (2007) Gallstone disease. J Intern Med 261: 529542.

18. Gore RM, Thakrar KH, Newmark GM, Mehta UK, Berlin JW (2010) Gallbladder imaging. Gastroenterol Clin North Am 39: 265-287, ix.

19. Avgerinos C, Kelgiorgi D, Touloumis Z, Baltatzi L, Dervenis C (2009) One thousand laparoscopic cholecystectomies in a single surgical unit using the "critical view of safety" technique. J Gastrointest Surg 13: 498-503.

20. Jaunoo SS, Mohandas S, Almond LM (2010) Postcholecystectomy syndrome (PCS). Int J Surg 8: 15-17.

21. Bilhartz LE, Horton JD, Feldman M (1998) Gallstone disease and its complications. In Feldman M, Friedman S, Brandt JL, editors, Sleisenger and Fordtran's Gastrointestinal and liver disease: pathophysiology, diagnosis management. 6th ed. Philadelphia: WB Saunders Company: 948-972.

22. Russo MW, Wei JT, Thiny MT, Gangarosa LM, Brown A, et al. (2004) Digestive and liver diseases statistics, 2004. Gastroenterology 126: 1448-1453.

23. Goldacre MJ, Duncan ME, Griffith M, Davidson M (2011) Trends in mortality from appendicitis and from gallstone disease in English populations, 19792006: study of multiple-cause coding of deaths. Postgrad Med J 87: 245-250.

24. Attili AF, Carulli N, Roda E, Barbara B, Capocaccia L, et al. (1995) Epidemiology of gallstone disease in Italy: prevalence data of the Multicenter Italian Study on Cholelithiasis (M.I.COL.) Am J Epidemiol 141: 158-165.

25. Kratzer W, Kron M, Hay B, Pfeiffer MM, Kächele V (1999) [Prevalence of cholecystolithiasis in South Germany--an ultrasound study of 2,498 persons of a rural population]. Z Gastroenterol 37: 1157-1162.

26. Shaffer EA (2006) Gallstone disease: Epidemiology of gallbladder stone disease. Best Pract Res Clin Gastroenterol 20: 981-996.

27. Sakorafas GH, Milingos D, Peros G. Asymptomatic cholelithiasis: is cholecystectomy really needed? A critical reappraisal 15 years after the introduction of laparoscopic cholecystectomy. Dig Dis Sci. 2007; 52: 1313-1325.

28. Kang JY, Ellis C, Majeed A, Hoare J, Tinto A, et al. (2003) Gallstones--an increasing problem: a study of hospital admissions in England between 1989/1990 and 1999/2000. Aliment Pharmacol Ther 17: 561-569.

29. Halldestam I, Enell EL, Kullman E, Borch K (2004) Development of symptoms and complications in individuals with asymptomatic gallstones. $\mathrm{Br} \mathrm{J}$ Surg 91: 734-738.

30. Acalovschi M (1994) Strategii moderne în tratamentul litiazei biliare. ClujNapoca: Editura Dacia: 157.

31. Doggrell SA (2006) New targets in and potential treatments for cholesterol gallstone disease. Curr Opin Investig Drugs 7: 344-348.

32. Mansurov Kh Kh, Mirodzhov GK (2005) Pathogenetic therapy for gallbladder cholesterosis. Rossiyskiy Zhurnal Gastroenterologii, Gepatologii i Koloproktologii 6: 45-48.

33. Legorreta AP, Silber JH, Costantino GN, Kobylinski RW, Zatz SL (1993) Increased cholecystectomy rate after the introduction of laparoscopic cholecystectomy. JAMA 270: 1429-1432.

34. Zacks SL, Sandler RS, Rutledge R, Brown RS Jr (2002) A populationbased cohort study comparing laparoscopic cholecystectomy and open cholecystectomy. Am J Gastroenterol 97: 334-340. 
35. Reshetnyak VI (2012) Concept of the pathogenesis and treatment of cholelithiasis. World J Hepatol 4: 18-34.

36. Cazacov V (2006) Evaluarea rezultatelor activitatii chirurgicale în Republica Moldova 2005-2006. Arta Medica: 3-8.

37. Hotineanu V. Chirurgia (2008) (Curs selectiv), redactia noua. Chisinau: 847.

38. Berger MY, van der Velden JJ, Lijmer JG, de Kort H, Prins A, et al. (2000) Abdominal symptoms: do they predict gallstones? A systematic review. Scand J Gastroenterol 35: 70-76.

39. Lammert F, Matern S (2005) The genetic background of cholesterol gallstone formation: an inventory of human lithogenic genes. Curr Drug Targets Immune Endocr Metabol Disord 5: 163-170.

40. Katsika D, Grjibovski A, Einarsson C, Lammert F, Lichtenstein P, et al. (2005) Genetic and environmental influences on symptomatic gallstone disease: a Swedish study of 43,141 twin pairs. Hepatology 41: 1138-1143.

41. Grigorieva IN (2007) Major risk factors of cholelithiasis. Rossiyskiy Zhurnal Gastroenterologii, Gepatologii i Koloproktologii 6: 17-19.

42. Juvonen T, Kervinen K, Kairaluoma MI, Lajunen LH, Kesäniemi YA (1993) Gallstone cholesterol content is related to apolipoprotein E polymorphism. Gastroenterology 104: 1806-1813.

43. van Erpecum KJ, Portincasa P, Dohlu MH, van Berge-Henegouwen GP, Jüngst D (2003) Biliary pronucleating proteins and apolipoprotein $E$ in cholesterol and pigment stone patients. J Hepatol 39: 7-11.

44. Buch S, Schafmayer C, Völzke H, Becker C, Franke A, et al. (2007) A genomewide association scan identifies the hepatic cholesterol transporter ABCG8 as a susceptibility factor for human gallstone disease. Nat Genet 39: 995-999.

45. Portincasa P, Di Ciaula A, Vendemiale G, Palmieri V, Moschetta A, et al. (2000) Gallbladder motility and cholesterol crystallization in bile from patients with pigment and cholesterol gallstones. Eur J Clin Invest 30: 317-324.

46. Hofmann AF (2007) Biliary secretion and excretion in health and disease: current concepts. Ann Hepatol 6: 15-27.

47. Carey MC, Fromm H, Leuschner U (1996) Formation and growth of cholestero gallstones: the new synthesis. Bile acids-cholestasis-gallstones. Advances in basic and clinical bile acid research. Dordrecht: Kluwer: 147-175.

48. Hansel SL, DiBaise JK (2010) Functional gallbladder disorder: gallbladder dyskinesia. Gastroenterol Clin North Am 39: 369-379, x.

49. Ko CW (2006) Risk factors for gallstone-related hospitalization during pregnancy and the postpartum. Am J Gastroenterol 101: 2263-2268.
50. Chang Y, Sung E, Ryu S, Park YW, Jang YM, et al. (2008) Insulin resistance is associated with gallstones even in non-obese, non-diabetic Korean men. J Korean Med Sci 23: 644-650.

51. Sahi T, Paffenbarger RS Jr, Hsieh CC, Lee IM (1998) Body mass index, cigarette smoking, and other characteristics as predictors of self-reported, physiciandiagnosed gallbladder disease in male college alumni. Am J Epidemiol 147: 644-651.

52. Tsai CJ1, Leitzmann MF, Willett WC, Giovannucci EL (2004) Prospective study of abdominal adiposity and gallstone disease in US men. Am J Clin Nutr 80: 38-44.

53. Tsai CJ, Leitzmann MF, Willett WC, Giovannucci EL (2006) Weight cycling and risk of gallstone disease in men. Arch Intern Med 166: 2369-2374.

54. Festi D, Dormi A, Capodicasa S, Staniscia T, Attili AF, et al. (2008) Incidence of gallstone disease in Italy: results from a multicenter, population-based Italian study (the MICOL project). World J Gastroenterol 14: 5282-5289.

55. Fornari F, Civardi G, Buscarini E, Cavanna L, Imberti D, et al. (1990) Cirrhosis of the liver. A risk factor for development of cholelithiasis in males. Dig Dis Sci 35: 1403-1408.

56. Novacek G (2006) Gender and gallstone disease. Wien Med Wochenschr 156 527-533.

57. Völzke H, Baumeister SE, Alte D, Hoffmann W, Schwahn C, et al. (2005) Independent risk factors for gallstone formation in a region with high cholelithiasis prevalence. Digestion 71: 97-105.

58. Sheffield KM, Ramos KE, Djukom CD, Jimenez CJ, Mileski WJ, et al. (2011) Implementation of a critical pathway for complicated gallstone disease: translation of population-based data into clinical practice. J Am Coll Surg 212 835-843.

59. Thijs C, Knipschild P, Brombacher $P$ (1990) Serum lipids and gallstones: a case-control study. Gastroenterology 99: 843-849.

60. Corradini SG, Elisei W, Giovannelli L, Ripani C, Della Guardia P, et al. (2000) Impaired human gallbladder lipid absorption in cholesterol gallstone disease and its effect on cholesterol solubility in bile. Gastroenterology 118: 912-920.

61. Busch N, Lammert F, Matern S (1996) Imbalance of biliary pronucleating and antinucleating factors in cholesterol gallstone formation. Bile Acids-CholestasisGallstones. Advances in Basic and Clinical Bile Acid Research. Dordrecht Kluwer: 194-202.

62. Mathus-Vliegen EM (2008) Intragastric balloon treatment for obesity: what does it really offer? Dig Dis 26: 40-44. 